\title{
Digital violence and children under five: The Phantom Menace within digital homes of the $21^{\text {st }}$ century?
}

\author{
Ioanna Palaiologou ${ }^{1}$
}

\begin{abstract}
This article aims to take stock of the research on parental perspectives on potential of digital violence among children under five years. This projects aimed to investigate parents' views on to what extent young children might be at risk of digital violence when interacting with digital technology; if is so what types of digital violence might be at risk; to what extent there are any similarities and any differences in the classification of risks proposed by EU Kids Online (2015).
\end{abstract}

Keywords: digital violence, children, education.

\section{Introduction}

In the past two decades there is a rapid increase in the use of digital technology by young children and suggest that children from a very young age use a range of digital devices (Plowman, 2015; Terreni, 2011; Palaiologou, 2016a) and their "digital imprint begins from birth" (Palaiologou, 2016b, p. 305). As research suggest young children are interacting with digital technology in a number of ways but evidence suggest that the main device children tend to use are tablets (Dunn, Gray, Moffet and Mitchell, 2016). In 2015 , it was reported that $73 \%$ of children under the age of five had access to a tablet (ChildWise, 2015) and to the internet. In 2016 Ofcom reported that in UK tablet ownership among children under five is increasing and replacing laptops to become the device children use most either to go on line or play games. Similarly studies from Europe (Chaurdon, 2015) Australia (Fleer, 2013a) and the USA (Rideout, Foehr, and Roberts, 2010) conclude that children from a very young age are owning and using tablets for a number of activities such as to watch YouTube videos and play games.

At the same time a body of research is not only exploring the impact of the use of digital technology in young children's learning and development (such

\footnotetext{
${ }^{1}$ CPsychol AFBPsS, FRSA.
} 
as Chau, 2014; Plowman and McPake, 2013; Plowman, 2015) but also the risks it might entail, including digital violence (such as Ofcome, 2016; Lobe et al., 2011; Livingstone, 2015; Kabali et al., 2015; Radesky et al., 2016; Rosebary et al., 2014; Ólafsson et al., 2014). Substantial research across many countries thus focuses on the potential risks that children are exposed with the use of internet (Byrne, Kardefelt-Winther, Livingstone and Stoilova, 2016; Blum-Ross, and Livingstone, 2016a and b).

In UK the most recent comprehensive research conducted by Ofcom and published in November 2016 surveyed parents with children from the ages of 3-15 in regards to the main concerns they have with their children using digital technology. These were: the amount of time their children spent watching television, going online, playing games and using a mobile phone.

Academic research has also focused on the risks of exposure to violence in a digital environment have been addressed and the terms 'cyber safety' now is widely used. Livingstone and Haddon (2009) in a study on EU countries and children's safety have classified the risks of the internet. In January 2017 the Children's Commissioner in England published a report that stated in regards to digital risks children even from the age of three are now accessing the internet and although there is some good progress in terms of on line protection for young children still more work is needed "to create a supportive digital environment for children and young people" (p. 3).

Despite evidence that children from a very young age are interacting with digital technologies there is still limited research examining whether there are any potential risks for violence among children under five that use digital technology and into their parents' concerns.

Thus this paper reports a small scale research on parental perspectives on potential of digital violence among children under five years. This projects aimed to investigate parents' views on:

- to what extent young children might be at risk of digital violence when interacting with digital technology;

- if is so what types of digital violence might be at risk;

- to what extent there are any similarities and any differences in the classification of risks proposed by EU Kids Online (2015) (full study by Livingstone, Sonia, Mascheroni, Giovanna and Staksrud, Elisabeth (2015) Developing a framework for researching children's online risks and opportunities in Europe. EU Kids Online, London, UK).

\section{Towards an understanding of digital violence}

Ten years ago the UN's vision was to raise awareness towards violence against children in an attempt to prevent it (2016 UN Global study on violence 
against children). In 2015 the UN Special Representative on Violence against Children emphasised that the prevention of violence was their second highest priority after education. The World Health Organization (2002, p. 4) defines violence as:

The intentional use of physical force or power, threatened or actual, against oneself, another person, or against a group or community, that either results in or has a high likelihood of resulting in injury, death, psychological harm, maldevelopment or deprivation.

In 2016, The UN Commission of Human Rights posted a comment on children and violence identifying types of in the digital environment:

Children are increasingly exposed to violence through the Internet. They risk coming into contact with illegal or harmful content, including pornography, and content inciting substance abuse, suicide and other forms of self-harm. The Internet is also used by predators to contact children under false identities with a view to abusing them. Moreover, children can themselves become perpetrators and inflict harm on others, notably by bullying other children on social media (https://www.coe.int/en/web/ commissioner/-/no-violence-against-children-is-acceptable-all-violence-is-preventable).

Thus research on digital violence defines it as using digital devices such as mobile phones, videos, cameras in order to intentionally cause harm (such as physical, sexual, verbal, cultural, psychological). The EU Kids Online (2015) surveyed 9-16 year olds and their parents in 25 countries to examine potential risks to children when they are on line and classified the following potential risks (Table 1):

Table 1 - Classification of online risks for children

\begin{tabular}{|l|l|l|l|}
\hline Risk & $\begin{array}{l}\text { Content: } \\
\text { Child as recipient }\end{array}$ & $\begin{array}{l}\text { Contact: } \\
\text { Child as participant }\end{array}$ & $\begin{array}{l}\text { Conduct: } \\
\text { Child as actor }\end{array}$ \\
\hline Commercial & $\begin{array}{l}\text { Advertising, spam, } \\
\text { sponsorship }\end{array}$ & $\begin{array}{l}\text { Tracking/harvesting } \\
\text { personal info }\end{array}$ & $\begin{array}{l}\text { Gambling, illegal } \\
\text { downloads, hacking }\end{array}$ \\
\hline Aggressive & $\begin{array}{l}\text { Violent, gruesome/hateful } \\
\text { content }\end{array}$ & $\begin{array}{l}\text { Being bullied harassed or } \\
\text { stalked }\end{array}$ & $\begin{array}{l}\text { Bullying or harassing } \\
\text { another }\end{array}$ \\
\hline Sexual & $\begin{array}{l}\text { Pornographic, harmful } \\
\text { sexual content }\end{array}$ & $\begin{array}{l}\text { Meeting strangers, being } \\
\text { groomed }\end{array}$ & $\begin{array}{l}\text { Creating uploading } \\
\text { pornographic material }\end{array}$ \\
\hline Values & $\begin{array}{l}\text { Racist, biased info/advice } \\
\text { (e.g. drugs) }\end{array}$ & $\begin{array}{l}\text { Self-harm, unwelcome } \\
\text { persuasion }\end{array}$ & $\begin{array}{l}\text { Providing advice e.g. } \\
\text { suicide/anorexia }\end{array}$ \\
\hline
\end{tabular}

Adopted by Livingstone, Sonia, Mascheroni, Giovanna and Staksrud, Elisabeth (2015) Developing a framework for researching children's online risks and opportunities in Europe. EU Kids Online, London, UK 


\section{Objectives of the research}

The primary goal of the research was to establish what parents of children under five think that:

1. Digital violence is.

2. To what extent they think their children are at risk of digital violence when interacting with digital technology at home.

3. What types of digital violence to which children might be at risk.

4. What competencies adults/parents should develop in using digital technologies in relation to protection of digital violence and their capacities to prevent and resolve digital violence.

\section{The Study}

This research project reported here was part of a research project examining the use of digital technologies at home and school of children under the age of five (Palaiologou, 2016a and b).

For this part of the study focus groups interviews were conducted with parents $(8$ parents in seven groups, total of 56 parents, 32 mothers and 24 fathers). The research reported here was conducted in England and the participants had children from ages of birth to 5 years of age who had access to the internet at home and ownership of at least one digital device (such as tablet, smart or iPhone, smart TVs). Seven focus groups were conducted of parents who had children from birth to 2years, 2-3 and 3-5 years. Parents who participated in this research were from diverse socioeconomic and educational backgrounds including four single parents. Their ages varied between 23 the younger parent and 43 the older one.

All parents gave their consent to participate in the focus groups and secondary permission to use the material. The ethical guidelines of British Education Research Association was followed during the project.

\section{Structure of focus groups interviews}

Parents were shown the World Health Organisation's definition on violence and the classification of types of digital violence (please see Table 1 above) and were asked to what extent they considered this is relevant to the ages of their children when using digital devices. The key themes of the focus groups interviews were on TV based activities (such as watching, accessing games with Wii or Kinnect or Xboxes), Internet based activities (such as playing games, using applications, watching YouTube videos), tablet and computer based activities (such as playing games, using them for activities such as drawing, reading, writing). 


\section{Results-Discussion}

The focus groups interviews were audio recorded, transcribed and thematically analysed. There were no significant differences between mothers and fathers as well as no significant difference in parents age, education and socioeconomic status. In all groups of parents it was evident that parents are allowing their children to use digital devices (such as tablets and iPhones or smart phones) mainly for games, to watch YouTube programmes (mainly with the parents) or watch TV programmes. Parents stated that their children mainly used the digital devices for fun and less for educational purposes. Although parents said that their children were using digital devices that were connected to the internet and they were using the internet for certain activities such as games or watching YouTube, they claimed that they did not feel that their children were exposed to risks. Thematic analysis revealed the following topics: types and nature of violence.

\section{Types of violence}

Parents were shown the types of violence according to WHO (2002) and were asked in their view whether they think these types of violence can be described as digital violence. The types of violence were:

Table 2 - Types of violence

\begin{tabular}{|l|l|}
\hline $\begin{array}{l}\text { Types of violence } \\
\text { and abuse }\end{array}$ & Explanation \\
\hline Physical violence & $\begin{array}{l}\text { When someone uses a part of their body or an object to control a person's } \\
\text { actions }\end{array}$ \\
\hline Emotional violence & $\begin{array}{l}\text { When someone says or does something to undermine a person or feel } \\
\text { stupid, worthless }\end{array}$ \\
\hline Sexual violence & When a person is forced to unwillingly take part in sexual activity \\
\hline Psychological violence & $\begin{array}{l}\text { When someone uses threats and causes fear in an individual to gain } \\
\text { control }\end{array}$ \\
\hline Cultural violence & $\begin{array}{l}\text { When one is harmed as a result of practices that are part of her or his } \\
\text { culture, religion or tradition }\end{array}$ \\
\hline Spiritual violence & $\begin{array}{l}\text { When someone uses an individual's beliefs to manipulate, dominate or } \\
\text { control that person }\end{array}$ \\
\hline Verbal abuse & $\begin{array}{l}\text { When someone uses language whether spoken or written to cause harm } \\
\text { to an individual }\end{array}$ \\
\hline Neglect & $\begin{array}{l}\text { When someone has responsibility to provide care or assistance for an } \\
\text { individual but does not do so }\end{array}$ \\
\hline
\end{tabular}

Adopted by World Health Organisation, 2002 


\begin{tabular}{|c|c|c|c|c|c|c|c|c|c|}
\hline \multirow{4}{*}{ 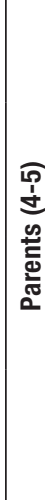 } & 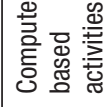 & 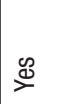 & 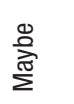 & $\stackrel{\mathscr{s}}{\rightleftharpoons}$ & $\stackrel{\infty}{\rightleftharpoons}$ & $\stackrel{\mathscr{\infty}}{>}$ & 离 & $\sum_{\substack{\tilde{\omega} \\
\Sigma}}^{0}$ & $\stackrel{\mathscr{S}}{=}$ \\
\hline & 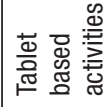 & $\stackrel{\mathscr{J}}{\rightleftharpoons}$ & 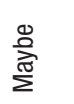 & $\stackrel{\mathscr{B}}{\rightleftharpoons}$ & $\stackrel{\mathscr{B}}{=}$ & $\stackrel{\infty}{=}$ & 竞 & 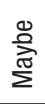 & $\stackrel{\infty}{=}$ \\
\hline & 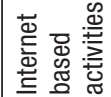 & $\stackrel{\infty}{=}$ & 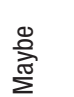 & $\stackrel{\infty}{\varnothing}$ & $\stackrel{\infty}{\rightleftharpoons}$ & $\stackrel{\mathscr{J}}{\varnothing}$ & $\begin{array}{l}\text { Dे } \\
\text { 离 } \\
\sum\end{array}$ & 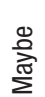 & 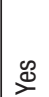 \\
\hline & 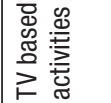 & $\stackrel{\mathscr{0}}{\check{0}}$ & $\begin{array}{l}\text { D) } \\
\text { 离 }\end{array}$ & $\stackrel{\infty}{\check{D}}$ & 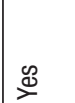 & $\stackrel{\mathscr{J}}{\check{2}}$ & 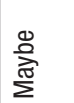 & 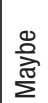 & 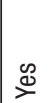 \\
\hline \multirow{4}{*}{ 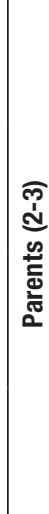 } & 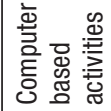 & $\stackrel{\mathscr{D}}{=}$ & 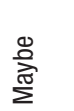 & q & $\stackrel{0}{2}$ & 离 & 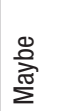 & 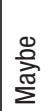 & 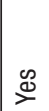 \\
\hline & 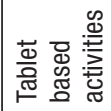 & $\stackrel{\infty}{\infty}$ & 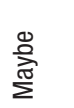 & 2 & 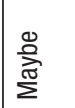 & 离 & 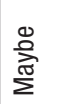 & 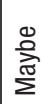 & $\stackrel{\infty}{\stackrel{\infty}{\infty}}$ \\
\hline & 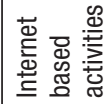 & $\stackrel{\infty}{\rightleftharpoons}$ & 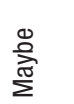 & o & $\stackrel{\mathscr{D}}{\rightleftharpoons}$ & $\stackrel{\mathscr{J}}{>}$ & 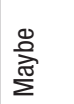 & 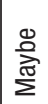 & $\stackrel{\infty}{\varnothing}$ \\
\hline & 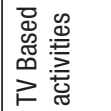 & $\stackrel{\mathscr{B}}{\longrightarrow}$ & 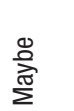 & 2 & $\stackrel{\mathscr{D}}{\rightleftharpoons}$ & $\stackrel{\infty}{\mathcal{\infty}}$ & 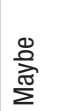 & 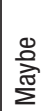 & $\stackrel{\mathscr{0}}{\check{0}}$ \\
\hline \multirow{5}{*}{ 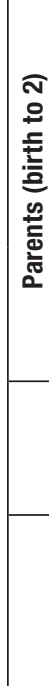 } & 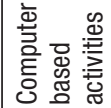 & 2 & $\stackrel{2}{2}$ & q & $\stackrel{0}{2}$ & $\stackrel{0}{2}$ & 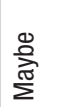 & 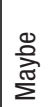 & $\stackrel{2}{2}$ \\
\hline & 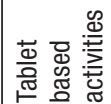 & 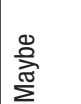 & $\begin{array}{l}\stackrel{0}{\bar{D}} \\
\sum \\
\sum\end{array}$ & 20 & $\underset{\infty}{\stackrel{\infty}{\infty}}$ & 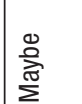 & 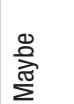 & 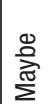 & $\mathscr{g}$ \\
\hline & 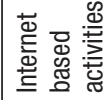 & 20 & $\stackrel{0}{2}$ & 20 & $\frac{1}{2}$ & 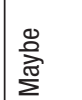 & $\begin{array}{l}\text { D. } \\
\text { 离 }\end{array}$ & 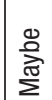 & $\stackrel{\mathscr{0}}{x}$ \\
\hline & 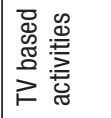 & 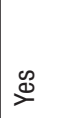 & 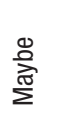 & $\stackrel{\mathscr{S}}{=}$ & $\stackrel{\mathscr{f}}{\rightleftharpoons}$ & 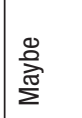 & 离 & 旡 & $\stackrel{\mathscr{0}}{\rightleftharpoons}$ \\
\hline & 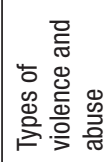 & 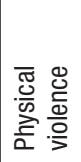 & 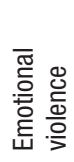 & 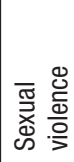 & 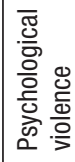 & 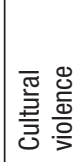 & 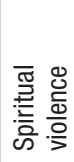 & 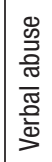 & $\begin{array}{l} \\
\frac{\tilde{\omega}}{2} \\
\frac{w}{2}\end{array}$ \\
\hline
\end{tabular}


Table 3 summarises the main responses of the parents to show there were some concerns on certain types of violence that might be caused by digital devices however, the rest of the themes shed light into the nature of digital violence according to the parents.

In terms of the types of risks described in Table 1 the parents agreed that they are similar to their concerns, but the nature of them is different and they felt it does not cover their own concerns for their children that are of much younger age. They agreed with the first category: Child as recipient and the subtypes, but they questioned (49 responses) whether the other two classifications (child as participant and child as actor) are applicable and appropriate for the children under five. 42 parents agreed that in terms of contact: child as participant they do see some relevant risks for their children the following types: commercial, (33 responses), aggressive (26 responses), sexual (9 responses), values (3 responses). No parents thought, however, that the third type Conduct: child as actor is relevant to the age group of their children.

\section{Nature of violence}

\section{Developmental Harm}

Parents in all groups raised concerns about the risk of potential developmental harm. Most common themes among the responses was the idea of physical harm. Parents were worried whether children are harmed by the use of digital devices as the physical use of the devices (such as tablets or smart phones or digital TVs) might harm children's health. They were concerned that the devices might expose their children to health issues as it is illustrated in the following quote:

these are all still new and we do not know what effect might have in children's health. We hear every day in the media a number of "experts" talking about these [devices] but we do not know the long term effect (mother of 2 years old).

The key issues on physical harm was children's eye health (42 responses) and using them might result to physical limited movements (36 responses) and with the use children are restrained from physical movement (46 responses). It was also a point for concern about the physical posture children have when they are holding when they are using a digital device (52 reponses).

Other aspects that concerned parents in terms of their children's development was language and social skills. (38 responses). They also expressed uneasiness with what the use of digital devices might cause to their children's language (32 responses) and social development (37 responses) and 
they perceived the use of digital device as activity that the child does not have opportunities in interacting linguistically or socially with others.

43 parents focused on the issue of modelling violence that is appearing in the content of some games their children play with digital devices or what they are watching in the videos. They express their worries about some of the content of apps or some of the games and programmes that they are recommended for young children include language and scenes that they found themselves inappropriate for children and they believe they give the wrong messages for children and hidden some form of violence.

\section{Parental neglect}

The majority of participants (53) raised their anxiety that they allow on occasions their children to use digital devices in order for them to get on with daily chores and errands as digital devices are keeping the attention and interest of their children for longer compare to other toys as it is illustrated in the following quote:

It is so convenient sometimes to allow my children to use my phone when we are shopping as I can do my shopping and my child concentrates without disturbing me... feel bad about this (father of 3,5 years old).

The terms "feel unease" appeared 27 times and the term "feel guilty" 46 times. As parents have noticed that children do get "absorbed" when they play with digital devices they felt some times they exploit this allowing their children to stay longer than they think they should in order for them to get on with daily practical aspects.

\section{Behavioural risks}

Parents raised issues about children's behaviours, especially children being addicted to digital devices, and they felt that they could not persuade their children to do something else. Most common children's behaviours that parents reported was shouting (34 responses), crying (36 responses), yelling (41 responses) and lying (23 responses). They also referred back to the types of violence (see Table 1) and 12 parents questioned whether this type of behaviour can be considered as verbal violence from their children towards them.

\section{Commercial exploitation}

Similar to other studies (Ofcom, 2016) this was another issue among the parents. They expressed the view that there are so many adverts that they cannot protect their children from. 
you try to show your child something on YouTube and then you have to see an advert without being able to skip it (father of 3 years old).

I do not get why they allow some adverts where they know children are watching [...] children cannot understand between reality and fiction, so how they can make sense of what happens? (mother of 4 years old)

Among the key issues with the commercial exploitation were the issue of the language these adverts use (43 responses), the images they are portraying (33 responses) and hidden inappropriate messages either of violence (28 responses) or some form of explicit or implicit sexual context (23 responses). The key concern they raised is that when their children come across these adverts that they cannot avoid to watch them with their children then they feel apprehension (36 responses) on how to deal with the children's questions.

\section{Social Media exploitation}

An issue of concern for parents was social media. Compared to other studies such as Livingstone 2016, Ofcom 2016, the parents' concerns were focusing around the social media (mainly Facebook) and how their children's photos are used (44 responses). Parents expressed concerns that photos of their children are taken and it so easy with the digital technology now for them to be placed on Facebook or in other open social media forums, in some cases without permission. Parents felt that this might exploit their children to certain risks such as images of their children might be used for insulting ( 23 responses) or even pornographic (11 responses) purposes. Parents mentioned that the social media are

full of photographs or videos of children and no one knows where this can end up and how they will be used (nother of 8 months)

although I filter my friends (meaning the friends on Facebook) ${ }^{2}$ when one of my friends does like me (meaning Like in Facebook) it goes to all sort of people (when one like someone's post on Facebook this automatically can go to all this person's friends on Facebook) so someone might use my babies' photos for all sort purposes and this is scary [...] yes I should not put them [photos] there but I like sharing my babies' photos with my friends (mother of 6 months 4 years old).

It was expressed that if children's photographs and personal spaces are so public then children can be "easy" targets for sexual penetrators (32 responses) or other risks such as kidnapping (11 responses), sexual abuse (24 responses) and physical harm (32 responses).

\footnotetext{
${ }^{2}$ In normal fonts researcher's explanations.
} 
Parents express their concerns that in the digital era privacy has been replaced with a need to share our private moments, with home moments becoming public without realising that this might entail potential risk to psychological violence (27 responses), physical violence (23 responses) and sexual violence (32 responses).

\section{Digital competencies}

In response to what competencies adults/parents should develop to protect their children when using digital technology and their capacities to prevent and resolve digital violence the key themes emerged where that instead of looking for competencies the focus should be in a culture that it evolves around:

- Trust vs Suspicion

- Dealing vs disbelief

- Detecting vs capacity

- Openness vs scepticism

- Contingencies vs causes

Parents felt that the focus should be on prevention, rather than worry about causes and results, and dealing with violence rather than the capacity to start looking for what caused it and how it can be dealt with.

\section{Conclusion - Implications}

Although this is a small scale research compare to EU Kids on line, this research is one of the first that examines the views of parents on potential risks to digital technology with children under five. All other studies so far examine the role of the internet in terms of risks to digital violence but this study examined the overall use of digital technology and not limiting only in the use of internet. It was found that parents have moved beyond the debate whether their children should or not use digital devices (Palaiologou, 2016a; Arnott, 2016; Marsh, Plowman, Yamanda-Rice, Bishop and Scott, 2016; Marsh and Bishop, 2014; Melhuish and Fallon, 2010). However, there are still some concerns on the use of digital devices that parents are finding themselves being "confused" and "without clear guidance".

As parents with very young children we always hear whether our children should use them or not, we never hear anything about the potential risks and we are left to make our own judgments (father of 2 years old).

They [media] only talk about the internet, but there are other concerns (mother of 4,6 years old). 
As mentioned earlier in this paper, the EU Kids on line have offered a typology of risks to digital violence from the internet for older children (915), but there is limited advice or guidance for parents with children under five. The parents in this study found the types of the risks to digital violence relevant to them and their children (see Table 1), but the nature was different. Moreover where the Ofcom report in 2016 has just started examining parents with children from 3-5 concerns, more research evidence is required from parents with children earlier in life as research is now showing evidence that children are using digital technology since birth. Only recently Edwards, Nolan, Henderson, Mantilla, Plowman and Skouteris (2016) have published their research where they examined how children aged 4-5 can be educated on issues of cyber safety. However, the results in the research reported in this paper have shown there are a number of parental concerns beyond the use of internet and these do need to be addressed at policy and practical level.

It is proposed by this research that at policy level there is a need to rethink and reconceptualise what digital violence is and the nature of this so it can include all children and not only children above the age of three years. It is also suggested that it might be appropriate to include other aspects of the digital technology in the definition and be extended beyond the use of internet. Equally academic research needs to focus on aspects of digital violence with the actual use of the devices among children under five and provide rigorous evidence that can be relative to and help parents of young children.

In January 2017 the Children's Commissioner in England published a report with the title "Growing up Digital: A report of the growing Up digital Workforce", where an amendment to UNCRC rights to reflect the digital era that the children are now living is proposed by Professor Livingstone:

The UN Convention on the Rights of the Child is an inspiring document which sets out what solely expects and demands for its children. Rights apply online as well offline, and now it's time to work how society can support children's rights in today's digital environments. A "General Comment" on children's rights in the digital age could really help make clear how children have the right to fair access and to the fabulous opportunities of the internet without significant risk of harm or infringement of their rights to privacy, communication, information, play and safety (p. 16).

It is suggested here that that these amendments should be extended to include children under five and include how children have the right to "fair access" as well as use of digital devices (and not only the internet) with emphasis on the development rights and protection rights. More specifically the UN Convention must be seen as applying to all children using digital technology and not only the ones who access the internet only. As all the rights are linked, and no right is more important that another, emphasis should 
be placed on The right to relax and play (Article 31) and the right to freedom of expression (Article 13) too have equal importance as the right to be safe from violence (Article 19) and the right to education (Article 28). They need to be amended in order to reflect that "digital imprint begins from birth" (Palaiologou, 2016b, p. 305). Research that has been discussed elsewhere tends to take little notice of children under five, but yet again the parents and children of this group age have concerns and these should not be overlooked.

At policy and practice level the focus should be placed on parental advice. Relying on parents of children under five solely to be proactive and protective or judge a safer use of digital devices can be problematic as academic research and media influence have left them feeling confused. The use of digital devices should be equal and shared responsibility between parents and early childhood education as it has become for other levels of education and move away from the debate on whether digital devices should be integrated or not in order to support parents and children on how it can be used in a safe way. The results in this research demonstrated that parents have a number of concerns related to the nature of digital violence and as one of the father's in the project stated: "digital devices are now in our homes, they are here and they will stay, but have we invited a Phantom Menace in our homes?"

Thus it is concluded that a synergistic joined thinking at policy and research level of how all children can use digital devices and not only the internet should be developed so parents and children can be supported in order to feel capable of facing the unknown-known "Phantom Menace" in their homes.

\section{References}

Arnott, L. (2016). "The role of digital technologies", in Palaiologou, I. (eds.), The early years foundation stage: theory and practice. London: Sage, pp. 329-341.

Blum-Ross, A. and Livingstone, S. (2016a). Families and screen time: current advice and emerging research. LSE Media Policy Project, Media Policy Brief 17. The London School of Economics and Political Science, London, UK.

Blum-Ross, A. and Livingstone, S. (2016b). "From youth voice to young entrepreneurs: the individualization of digital media and learning", Journal of Digital and Media Literacy. ISSN 2326-1862.

Byrne, J., Kardefelt-Winther, D., Livingstone, S. and Stoilova, M. (2016). Global Kids Online: research synthesis 2015-2016. UNICEF, The London School of Economics and Political Science, London, UK.

Chau, C.L. (2014). Positive technological development for young children in the context of children's mobile app. America: Tufts University.

Chaudron, S. (2015). "Young children (0-8) and digital technology: a qualitative exploratory study across seven countries", Joint Research Centre European Commission, DOI: 10.2788/00749. 
Children's Commissioner (2017). Growing Up Digital: A report of the Growing Up Digital Taskforce, https://www.childrenscommissioner.gov.uk/publications/growingdigital (accessed 17th Jan 2017).

Childwise (2015). The monitor pre-school report: key behaviour patterns among 0-4 year olds. London: Childwise.

Dunn, J., Gray, C., Moffett, P. and Mitchell, D. (2016). "It's more funner than doing work': children's perspectives on using tablet computers in the early years of school", Early Child Development and Care: 1-13. doi: 10.1080/ 03004430.2016.1238824

Edwards, S., Nolan, A., Henderson, M., Mantilla, A., Plowman, L., and Skouteris, H., (2016). "Young children's everyday concepts of the internet: A Platform for cybersafety education in the early years", British Journal of Educational Technology, DOI: $10.1111 /$ bjet.12529.

Fleer, M. (2013a). "Digital Positioning for Inclusive Practice in Early Childhood: The Cultural Practices Surrounding Digital Tablets in Family Homes", Computers in New Zealand Schools: Learning, Teaching, Technology, 25 (1-3): 56-76.

Fleer, M. (2013b). Theorising Play in the Early Years. New York, NY: Cambridge University Press.

Kabali, H.K., Irigoyen, M., Nunez-Davis, R., Budacki J.G., Mohanty S.H., Leister, K.P. and Bonner Jr., R.L. (2015). "Exposure and use of Mobile Media Devices by Young Children", Pediatrics, 136 (6): 1044-1050.

Livingstone, S. and Haddon, L. (2009). EU Kids Online. Zeitschrift Für Psychologie/ Journal of Psychology, 217: 236.

Livingstone, S. (2016). How can children be protected online when the internet has been designed for adults? In: Children's Rights and the Internet: From Guidelines to Practice. London, UK: UNICEF, pp. 12-13.

Livingstone, S., Mascheroni, G. and Staksrud, E. (2015). Developing a framework for researching children's online risks and opportunities in Europe. London, UK: EU Kids Online.

Lobe, B., Livingstone, S., Ólafsson, K. and Vodeb, H. (2011). Cross-National Comparison of Risks and Safety on the Internet: Initial analysis from the EU Kids Online survey of European children.

Marsh, J. and Bishop J.C. (2014). Changing Play: Play, Media and the Commercial Culture from 1950s to the Present Day. Maidenhead: open university Press.

Marsh, J., Brooks, G., Hughes, J., Ritchie, L., Roberts, S. and Wright, K. (2005). Digital Beginnings: Young Children's Use of Popular Culture, Media. University of Sheffield: Literacy Research Centre.

Marsh, J., Plowman, L., Yamanda-Rice, D., Bishop, J. and Scott, F. (2016). "Digital play: A new classification", in Early Years: An International Research Journal, vol. 36 (3): 242-253.

Melhuish, K. and Falloon, G. (2010). "Looking to the Future: M-Learning with the iPad", Computers in New Zealand Schools: Learning, Leading, Technology, 22 (30): 1-15.

Mills, S.C., and Tincher, R.C. (2003). "Be the Technology", Journal of Research on Technology in Education, 35 (3): 382-401. 
Ofcom (2016). Children and parents: media use and attitudes report, https://www. ofcom.org.uk/research-and-data/media-literacy-research/children/children-parentsnov16 (accessed 28 Nov 2016).

Ólafsson, K., Livingstone, S. and Haddon, L. (2014). Children's Use of Online Technologies in Europe: A Review of the European Evidence Base. LSE, London: Eu Kids online. Second edition. Accessed November 25, 2015. www. 1se.ac.uk/media@1se/research/EuKidsonline/Eu\%20Kids\%20III/Reports/ D2.2RevisedEvidenceReview_sept2014.pdf33.

Palaiologou, I. (2016a). "Children under Five and Digital Technologies: Implication for Early Years Pedagogy", The European Early Childhood Research Journal, 24 (1): 5-24. DOI: http://dx.doi.org/10.1080/135029 3X.2014.929876.

Palaiologou, I. (2016b). Teachers' Dispositions towards the role of digital devices in play-based pedagogy in early childhood education, Early Years An International Research Journal, vol. 36 (3): 305-321. DOI: 10.1080/09575146.2016.1174816.

Plowman, L. (2015). "Researching Young Children's Everyday uses of Technology in the Family Home", Open access in Interacting with Computers, 27 (1): 36-46.

Plowman, L. and McPake, J. (2013). "Seven Myths about Young Children and Technology", Childhood Education, 89 (1): 27-33.

Radesky, J.S., Kistin, C.J., Zuckerman, B., Nitzberg, K., Gross, J., Kaplan-Sanoff, M., Augustyn, M. and Silverstein, M. (2014). "Patterns of Mobile Device use by Caregivers and Children during Meals in Fast Food Restaurants", Pediatrics, 133 (4). www.pediatrics.org/cgi/content/full/133/4/e843.

Radesky, J.S., Kistin, C., Eisenberg, S., Zuckerman, B. and Silverstein, M. (2015). Parent Views about Mobile Device use around and by Young Children: Implications for Anticipatory Guidance. Abstract presented at the Pediatric Academic Societies, San Diego, CA. Accessed Feb 4, 2016. www.abstracts2view. com/pas/view.php?nu=PAS15L1_2195.2.

Rideout, V., Foehr, U.G. and Roberts, D. (2010). Generation M2: Media in the Lives of 8- to 18-Year-Olds. Menlo Park, CA: Henry J. Kaiser Family Foundation.

Roseberry, S., Hirsh-Pasek, K. and Golinkoff, R.M. (2014). "Skype Me! Socially Contingent Interactions Help Toddlers Learn Language", Child Development, 85 (3): 956-970.

Terreni, L. (2011). "Interactive Whiteboards, Art and Young Children", Computers in New Zealand Schools: Learning, Teaching, Technology, 23 (1): 78-100.

World Health Organization (2002). World report on violence and health: summary. Geneva, World Health Organization. 